\title{
Teachers' Perceptions about the Use of Mother Tongue in Saudi EFL University Classrooms: A Gender-line Investigation
}

\author{
AbdulRahman Al Asmari \\ English Language Center, Taif University, Taif, KSA
}

\begin{abstract}
This paper attempts to investigate the awareness about the use of the mother tongue (MT) in the Saudi EFL university classrooms. The use of MT can be a cause of encouraging or de-motivating source in the discourse of Saudi EFL Preparatory Year Program (PYP) classrooms. This phenomenon is investigated from the teachers' viewpoint in the present study. Focusing on the perceptual nature of the study, a survey was conducted to assess the significance of MT use amongst male and female teachers in EFL classes within the context of Saudi PYP. The participants consisted of 100 EFL teachers [males \& females] drawn from PYP Taif University English Language Centre (TUELC). A 22-item Likert-scale questionnaire was developed to elicit their perceptions of various academic uses of MT in an EFL context of Saudi universities. The findings of the present study reflect that EFL teachers within the context of Saudi PYP represented by the cohort of this study bears quite positive perceptions towards the use of MT. It is also concluded that they believe that teaching/learning a foreign language is easier if teaching is not merely limited to the target language (TL). Moreover, the results of the present study reflected that the cohort of both groups approved the significance of different functions of MT in the Saudi EFL university classrooms. However, male and female EFL teachers' perceptions about the use of MT were not on the same-line.
\end{abstract}

Index Terms - mother tongue, EFL teaching, EFL male and female teachers, Saudi context, and PYP

\section{INTRODUCTION}

In recent years, applied linguists, speech experts, and discourse analysts working in the area of education have dramatically expanded the scope of their research to address critical areas of classroom discourse in language learning and acquisition. Learning a foreign/second language differs from learning other academic subjects. Brown (1995, p. 31) theorized that learning another language requires such a devotion on the part of learners that "your whole person is affected as you struggle to reach beyond the confines of your first language and into a new language, a new culture, a new way of thinking, feeling, and acting". Furthermore, the learners who are involved in learning a new language also vary in terms of factors like attitudes, motivation, learning style, age, gender, aptitude (Grosjean \& Soares, 1984). The same point has also been emphasized by Wenden (1991, p. 32) who stated that "the notion of learner-centred instruction in foreign and second languages grew out of the recognition that language learners are diverse in their reasons for learning another language, their approach to learning, and their abilities". A growing mass of research investigated the significance of learning English as a second/foreign language to better understand the learners' classroom discourse patterns that are instrumental in achieving effective and efficient teaching/learning practices in the classrooms. The issue of MT in Foreign Language Teaching (FLT) had not been a crux of scientific studies in nonEnglish speaking countries, but recent use of MT has attracted a considerable amount of attention of the researchers. Fundamentally, the tradition of language alternation became known with the ban on the use of the learners' first language (L1) in FLT, and it was introduced by the Direct Method at the end of the nineteenth century (Cook, 2001). Although some uses of MT are acceptable for communicative language teaching methodology, there is still a debate over these accepted uses. For example, some of the linguists argue that the open view towards the use of MT may lead to an overuse and inadvisable use of it by teachers (Ellis, 1985). However, supporters of the exclusive use of the TL are losing ground and most researchers now argue in favour of a more tolerant approach towards MT (Eastman, 1995). In the context of Saudi Arabia, insufficient attention is paid to investigate the awareness of using MT in Saudi EFL university classrooms, namely in PYPs. Therefore, there is an emerging need to develop more understanding of this phenomenon in the context under study. The present study is an attempt to find out the perceptions of Saudi university EFL teachers [males and females] towards the use of MT along gender lines.

\section{OBJECTIVES OF THE STUDY}

The following points define the objectives of the study:

i. To examine the perceptions of Saudi university EFL teachers [males \& females] towards the use of MT in the context of Saudi PYP classrooms. 
ii. To find out the significance of MT as a method from the angle of male and female teachers' perceptions in PYP EFL classrooms of Saudi universities.

iii. To investigate the utility of different functions of MT in the context of PYP EFL classrooms of Saudi universities.

\section{DELimitations OF THE STUDY}

This study is delimited to explore and analyze the perceptions of EFL teachers about the use of MT in the context of Saudi PYP EFL classrooms. For this purpose, the researchers attempted to develop a questionnaire in a suitable form to decipher the EFL teachers' awareness about the use of MT in Saudi universities.

\section{LITERATURE REVIEW}

There are a number of attitudes, approaches and methods which advocate for or against the use of MT in the EFL and ESL classrooms. For example, researchers who belong to Grammar Translation Method (GTM) schools believe that a little use of MT plays a positive role in foreign language learning (Brumfit, 1984). Coder (1981, p. 198) provides a justification from a different viewpoint and claims that "second language learners not only already possess a language system which is potentially available as a factor in the acquisition of a second language, but equally important they already know something of what a language is for, what its communicative functions and potentials are." From a bilingual perspective, cultural anthropologist Heath (1986, p. 186) asserts that to reject a child's language in the school is to reject the child. In addition, (Macswan, 1999) points out that instruction plays an important role in second language learning and that it adds to L2 learning in crucial respects. Contrary to the ideas that two languages confuse people, there is evidence that well-developed bilingualism actually enhances one's "cognitive flexibility" Grosjean (1982). Skutnabb-Kangas (2000, p 185) stresses the significance of learning a foreign language and claims that bilingualism has positive effects on children's linguistic and educational development. When children continue to develop their abilities in two or more languages throughout their primary school years, they gain a deeper understanding of language as how to use it effectively.

Speaking culturally, Heller (1992, p. 118) provides a different justification for the use of L1 in these words, "if you are an ESL teacher and/or you teach minority children through the medium of a dominant language, at the cost of their mother tongue, you are participating in linguistic genocide". Moreover, UNESCO (1953) explicitly supports that a mismatch between home language and school language is the major cause of poor academic achievement of minority children. The findings of that report stated: It is axiomatic that the best medium for teaching a child is his mother tongue. Psychologically, MT is the system of meaningful signs that his mind works automatically for expression and understanding. Sociologically, it is a means of identification among the members of the community to which he belongs. Educationally, he/she learns more quickly through MT than through an unfamiliar linguistic medium. Also, it has been argued that when the official code marginalizes particular culture and class group, there is a danger of alienating the student, either from the home community or from the education. Skutnabb-Kangas similarly (2000) advocates literacy model for minority children in India, in which literacy is first introduced in the child's mother tongue; once the basic literacy skills are attained, the curriculum transfers to a formal language of education. In EFL contexts, Nunan and Lamb (1996) contend that EFL teachers working with monolingual students at lower levels of English proficiency find the prohibition of MT to be practically impossible. Dornnyei (1998, p. 349) find that MT is used by L2 learners as a communication strategy to compensate for deficiencies in the TL. Disciullo (1986) conducted a study with EFL students and their teachers in a Spanish context to investigate their attitude toward using MT in the foreign language classroom. His results indicated that Spanish should be used in the EFL classroom.

In the Saudi context, the elite private sector of education usually relies on the English medium system, while in the public sector the medium of instruction is Arabic. The reasons for this dichotomy may be due to socio-linguistic and ethnic norms in the Saudi tribal society. Moreover, English medium schools teach English in the context of second language learning (e.g. where English is spoken in and outside the classrooms), while the public education English is widely used as a compulsory subject in KSA. Accordingly, when the students enroll in the universities with this background, it is expected that they rely heavily on MT due to their lack of high English proficiency. Consequently, PYP EFL classes are mixed ability classes. Several studies have argued that English Language Teaching (ELT) in the Arab world has not produced the desired results (Rababah, 2003; Sahu, 1999; Zughoul, 1986). Abed (2003) has mentioned that despite spending around $6 \%$ of their Gross Domestic Production (GDP), the Arab nations of the Middle East and North Africa are still far behind in achieving effective ELT. Much research has suggested that Arab students of English are unable to achieve desired proficiency in TL, even after formally studying English for many years (Abbad, 1998). Similarly, other studies reported that Arab students' English proficiency level is much below the proficiency level of the students from other parts of the world (Sahu, 1999). In such situations, Baker \& Jones (1998) suggests that students regularly make covert use of their languages to accomplish learning tasks set in classrooms, often mixing and sharing terms from each other's language, and schools merely need to embrace what is already happening naturally. On the basis of the review of the above mentioned studies, it is clear that two streams of consciousness (i.e. English medium schools and Arabic medium schools) are in the process of creation. In this study, therefore, EFL university teachers' perceptions about the use of MT in the interactional patterns of Saudi PYP EFL classrooms are investigated. 


\section{RESEARCH QUESTIONS}

The following research questions are investigated in order to find out the different use(s) of MT in Saudi PYP EFL classrooms.

Q.1. What are the EFL teachers' perceptions of the use of MT in the classroom in the Saudi PYP?

Q.2. How do EFL teachers [males and females] identify gender-based differences towards the behavioral intentions of MT in the Saudi universities EFL classrooms?

Q.3. How do EFL teachers [males and females] reflect gender-based differences towards the reasons that enhance the use of MT in the Saudi universities EFL classrooms?

\section{HYPOTHESES}

This study has the following hypotheses:

H1. There are statistically gender-based differences in the perceptions of EFL teachers [males and females] towards the perceived effectiveness of MT in Saudi universities EFL classrooms.

H2. There are statistically gender-based differences in the perceptions of EFL teachers [males and females] towards the behavioral intentions of MT in Saudi universities EFL classrooms.

H3. There are statistically gender-based differences in the perceptions of Saudi universities PYP EFL teachers [males and females] towards the reasons that enhance the use of MT in Saudi universities EFL classrooms.

\section{RESEARCH METHODOLOGY}

\section{A. Design}

The design of this study is quantitative in nature in which a 5-point Likert-scale ranging as strongly disagree, disagree, uncertain, agree, strongly agree was developed based on the previous studies as a measuring instrument. The questionnaires were distributed among the participants to elicit their perceptions about the use of MT and its significance in English language teaching/learning process in the context of Saudi PYP EFL classrooms.

\section{B. Instrumentation}

The researchers consulted several studies that were conducted to elicit participants' perceptions towards various dynamics of English language teaching/learning through using questionnaires (e.g. Dehbozorgi, 2012; Soku, 2011; GOKCE, 2008; Karahan; 2007). The final instrument had 22 items divided into the following three sub-categories: $i$. PYP EFL teachers' [males and females] perceptions towards the perceived usefulness of MT (6 items), ii. perceptions of PYP EFL teachers [males and females] towards behavioral intentions of MT (6 items), and iii. perceptions of PYP EFL teachers [males and females] towards reasons that enhance the use of MT in the Saudi PYP EFL classrooms (10 items). The researchers managed to get 110 filled in questionnaires out of 120, and some of the incomplete questionnaires were discarded. Ninety four questionnaires were completed in all forms in which 51 were received from PYP EFL male teachers and 44 were received from PYP EFL female teachers from the staff of TUELC for the academic year 2013-2014.

\section{Statistical Analysis}

The researchers used the descriptive statistics, namely the means, medians, standard deviations and percentages for the analysis of the questionnaire. Independent samples T-test was also applied to identify any statistically significant differences in the perceptions of the male and female respondents of TUELC. The data generated through the questionnaires was manually entered, coded and analyzed using SPSS program aiming to answer the research questions and to test its hypotheses.

\section{Validity and Reliability}

The initial version of the questionnaire, which had 30 items, was given to three senior faculty members from TUELC to determine the face validity of the instrument. They were requested to suggest any appropriate changes to improve the quality of the instrument. Their comments were considered, and 6 items were deleted and other recommended changes were also incorporated before it was piloted to determine its reliability. The questionnaire was administered to 20 PYP EFL teachers of TUELC. Their responses were coded and the reliability coefficient test was run for the instrument as a whole and for its three parts separately using SPSS version 10.0. The Cronbach Alpha value remained .8838 for the instrument as a whole, which is a highly acceptable consistency of reliability.

\section{RESULTS AND DISCUSSION}

The present study data was statistically analyzed to generate the descriptive statistics and to identify any significant differences among respondents in their perceptions along gender lines. Results are presented and discussed thematically as follows: Attitudes towards the perceived effectiveness of MT, behavioral intentions towards the use of MT in Saudi PYP EFL classrooms, and perceptions about the use of different reasons for MT. 
A. Attitudes towards Perceived Effectiveness of $M T$

TABLE 1:

PYP TEACHERS' [MALES \& FEMALES] ATTITUDES TOWARDS THE PERCEIVED EFFECTIVENESS OF MT IN SAUDI PYP EFL CLASSROOMS

\begin{tabular}{|c|c|c|c|c|c|c|c|c|c|}
\hline \multicolumn{2}{|c|}{ Questionnaire Items } & \multirow{2}{*}{$\begin{array}{l}\text { Group } \\
\text { females }\end{array}$} & \multirow{2}{*}{$\begin{array}{ll}n \\
44\end{array}$} & \multirow{2}{*}{$\begin{array}{l}\mathrm{M} \\
3.4773\end{array}$} & \multirow{2}{*}{$\begin{array}{l}\text { SD } \\
1.21020\end{array}$} & \multirow{2}{*}{$\begin{array}{l}\mathrm{T} \\
-2.302-\end{array}$} & \multirow{2}{*}{$\begin{array}{ll}\mathrm{df} \\
93\end{array}$} & \multicolumn{2}{|c|}{$\mathrm{p}$ value } \\
\hline \multirow[t]{2}{*}{1} & \multirow{2}{*}{$\begin{array}{l}\text { Mother tongue helps develop interaction in Saudi } \\
\text { PYP EFL classrooms. }\end{array}$} & & & & & & & .000 & \multirow[t]{2}{*}{$\mathrm{p}<0.05$} \\
\hline & & males & 51 & 3.9608 & .82367 & $-2.240-$ & 74.064 & & \\
\hline \multirow[t]{2}{*}{2} & \multirow{2}{*}{$\begin{array}{l}\text { MT is a straight and instant method for teaching } \\
\text { purposes. }\end{array}$} & females & 44 & 3.7273 & 1.14858 & $-1.080-$ & 93 & .023 & \multirow[t]{2}{*}{$\mathrm{p}<0.05$} \\
\hline & & males & 51 & 3.9608 & .95835 & $-1.066-$ & 84.081 & & \\
\hline \multirow[t]{2}{*}{3} & \multirow{2}{*}{$\begin{array}{l}\text { MT is an easy and normal technique to understand } \\
\text { technical information. }\end{array}$} & females & 44 & 3.4773 & 1.04522 & $-.295-$ & 93 & .282 & \multirow[t]{2}{*}{$p>0.05$} \\
\hline & & males & 51 & 3.5490 & 1.28552 & $-.300-$ & 92.696 & & \\
\hline \multirow[t]{2}{*}{4} & \multirow{2}{*}{$\begin{array}{l}\text { MT helps accomplish teaching tasks more } \\
\text { successfully. }\end{array}$} & females & 44 & 3.5227 & 1.28477 & $-.718-$ & 93 & .002 & \multirow[t]{2}{*}{$\mathrm{p}<0.05$} \\
\hline & & males & 51 & 3.6863 & .92715 & $-.701-$ & 76.959 & & \\
\hline \multirow[t]{2}{*}{5} & \multirow{2}{*}{$\begin{array}{l}\text { MT increases the potential to understand language } \\
\text { materials in the target language. }\end{array}$} & females & 44 & 3.3182 & 1.25333 & $-1.062-$ & 93 & .083 & \multirow[t]{2}{*}{$\mathrm{p}>0.05$} \\
\hline & & males & 51 & 3.5686 & 1.04412 & -1.048 & 84.008 & & \\
\hline \multirow[t]{2}{*}{6} & \multirow{2}{*}{$\begin{array}{l}\text { MT elevates effectiveness of communicative } \\
\text { process in Saudi PYP EFL classrooms. }\end{array}$} & females & 44 & 3.4545 & 1.45402 & $-.735-$ & 93 & .012 & \multirow[t]{2}{*}{$\mathrm{p}<0.05$} \\
\hline & & males & 51 & 3.6471 & 1.09222 & $-.720-$ & 78.963 & & \\
\hline
\end{tabular}

The data analysis presented in Table 1 relates to the attitudes towards the perceived usefulness of MT along gender lines. Male and female cohort of the study showed significant differences in 5 items out of 6 items provided in the first section of the questionnaire. Both groups assigned the highest value to item 2 that elicited their responses towards their inclination to use MT 'as a straight and instant method' in Saudi PYP EFL classrooms, and female faculty members also ranked it at the highest level. Further, low standard deviation (i.e. 1.14858) (henceforth SD) reflects that female respondents were not divided about its significance. Saudi PYP EFL classrooms interactants' tendency to use MT may be attributed to their perceptions of MT as a way to help develop interaction with Saudi EFL classroom learners. This result goes in line with Gulzar's (2010), but in a whole different context (i.e. Pakistan). Cook (1989) also authenticates this finding and claims that switching between TL and MT may facilitate language development as a mechanism for providing language samples and may also be utilized as a teaching method for teaching second languages.

Moreover, the present study data revealed interesting findings as exhibited by the higher values assigned to items 1,2 , 4, and 6, by male respondents, and higher values were also assigned to items 2, 4, 3, and 1 by female respondents respectively. Besides, the data indicate that students wanted to use MT to learn TL because it would help them in their academic as well as professional life in KSA. Both male and female respondents reported that item 1 'mother tongue helps develop interaction in Saudi EFL classrooms' to accomplish different teaching tasks more effectively in Saudi EFL university classrooms. The respondents' views are similar to those reported by Faltis (1989) when he claimed that a strategy used by second language learners has been to employ the alternation of two languages as a bridge between the two languages they are learning. Crystal (1987, p. 14) best explained such a situation as "switching commonly occurs when an individual wishes to express solidarity with a particular social group. Rapport is established between a speaker and a listener when the listener responds with a similar switch". Moreover, both groups assigned the highest ranking to the second item 'MT is a straight and instant method for teaching purposes' and it is the only item in this section of the questionnaire that gained the same significance from both sample groups. On the other hand, item six 'MT elevates effectiveness of communicative process in Saudi EFL classrooms' was ranked fifth by female respondents. Item five 'MT increases the potential to understand language materials in the target language' was ranked fourth by female respondents. Conversely, item five was placed fifth, and item six is ranked as a third significant item by male respondents. Here data reflect the dichotomy between male and female respondents about the significance of items 5 and 6. The findings of the present research confirm that the use of MT should normally be motivated instrumentally and the role of MT is to enhance the communicative process. This finding is in accord with the research of Gulzar \& Al Asmari (2010). Data analysis also reveal that then there is an increasing awareness among EFL teachers [males and females] in Saudi universities about the students' need for the English language to fulfill their academic and daily chores of life.

The results of the present study reflect also that the participants did not consider MT as an important factor to accomplish all teaching tasks. Male and female faculty participants of the present study reported significant differences in items 1,5 , and 6 in section 1 of the questionnaire. Lower values were assigned by females (3.3182) and males (3.5686) respondents to item 5 'MT increases the potential to understand language materials in the target language', and lower values (females 3.4545, males 3.6471) were also assigned to item 6 'MT elevates effectiveness of communicative process in Saudi EFL classrooms'. Such results indicated that male and female EFL teachers did not support these two items. It is reported that these items were less important factors for the use of MT for both male and female respondents. It approves that PYP male and female EFL teachers are aware of the fact that complete reliance on the use of MT might bear negative consequences. As such, items 5 and 6 which consider that the use of MT elevates communicative competence among students were rejected by the respondents. Such results do not align with Cooks' claim (1991) that the practice of using MT makes students communicatively competent. Moreover, male respondents assigned moderate value to items 5 , and 3, indicating that relying on the MT even for teaching technical materials of TL might not be effective. The present study findings, therefore, are not in line with a study conducted by Al-Mutawa (1986) to elicit Saudi students' attitudes towards English language where the majority of the participants emphasized that Arabic 
should not be compromised by giving unnecessary importance to English language. This is an important finding that reflects a contradiction among interactants belonging to the same Saudi context (i.e. teachers vs. students). This issue may raise some concerns as the teachers' supply of MT is based on moderate and limited use, but students want to use it for all the purposes. On the other hand, females assigned moderate values to items 3,5 and 6 showing that though they did not rank them for the same positions but both groups placed them in the category of moderate items. Data analyses also revealed the existing differences between male and female faculty respondents on items 2,3 , 4, 5, and 6 . The values assigned by male and female PYP EFL teachers towards the perceived effectiveness of MT are mainly in favour of accepting the first hypothesis of the present study.

\section{B. Behavioral Intentions towards the Use of MT in Saudi PYP EFL Classrooms}

TABLE 2:

EFL TEACHERS' BEHAVIORAL INTENTIONS TOWARDS THE USE OF MT IN SAUDI PYP CLASSROOMS

\begin{tabular}{|c|c|c|c|c|c|c|c|c|c|}
\hline \multicolumn{2}{|c|}{ Questionnaire Items } & Group & $\mathrm{n}$ & $\mathrm{M}$ & SD & $\mathrm{T}$ & $\mathrm{df}$ & $\mathrm{p} \mathrm{vall}$ & \\
\hline \multirow[t]{2}{*}{7} & \multirow{2}{*}{$\begin{array}{l}\text { MT should be used in the Saudi university PYP } \\
\text { EFL classrooms. }\end{array}$} & females & 44 & 3.2045 & 1.50317 & $-1.175-$ & 93 & .000 & \multirow[t]{2}{*}{$\mathrm{p}<0.05$} \\
\hline & & males & 51 & 3.4902 & .80926 & $-1.127-$ & 63.765 & & \\
\hline \multirow[t]{2}{*}{8} & \multirow{2}{*}{$\begin{array}{l}\text { Teacher should consciously use MT in Saudi PYP } \\
\text { EFL university classrooms. }\end{array}$} & females & 44 & 3.5227 & 1.50176 & .126 & 93 & .009 & \multirow[t]{2}{*}{$\mathrm{p}<0.05$} \\
\hline & & males & 51 & 3.4902 & .98737 & .123 & 72.394 & & \\
\hline \multirow[t]{2}{*}{9} & \multirow{2}{*}{$\begin{array}{l}\text { Habits of using MT must be nurtured among the } \\
\text { Saudi PYP EFL university students. }\end{array}$} & females & 44 & 3.3636 & 1.41571 & 1.915 & 93 & .302 & \multirow[t]{2}{*}{$\mathrm{p}>0.05$} \\
\hline & & males & 51 & 2.8627 & 1.13172 & 1.884 & 82.039 & & \\
\hline \multirow{2}{*}{$\begin{array}{l}1 \\
0\end{array}$} & \multirow{2}{*}{$\begin{array}{l}\text { MT is an essential technique in Saudi PYP EFL } \\
\text { classroom discourse. }\end{array}$} & females & 44 & 3.7500 & 1.29624 & 1.714 & 93 & .689 & \multirow[t]{2}{*}{$\mathrm{p}>0.05$} \\
\hline & & males & 51 & 3.3529 & .95548 & 1.677 & 78.019 & & \\
\hline \multirow{2}{*}{$\begin{array}{l}1 \\
1 \\
\end{array}$} & \multirow{2}{*}{$\begin{array}{l}\text { Use of MT should be enhanced to boost up the } \\
\text { proficiency of Saudi PYP EFL students. }\end{array}$} & females & 44 & 3.6136 & 1.79425 & .478 & 93 & .015 & \multirow[t]{2}{*}{$\mathrm{p}<0.05$} \\
\hline & & males & 51 & 3.4706 & 1.08357 & .461 & 68.486 & & \\
\hline \multirow{2}{*}{\begin{tabular}{l|l}
1 \\
2
\end{tabular}} & \multirow{2}{*}{$\begin{array}{l}\text { Bilingual teachers can expedite the process of } \\
\text { learning English. }\end{array}$} & females & 44 & 3.8409 & 1.73799 & 1.216 & 93 & .275 & \multirow[t]{2}{*}{$p>0.05$} \\
\hline & & males & 51 & 3.4902 & 1.02708 & 1.173 & 67.542 & & \\
\hline
\end{tabular}

Table 2 comprehensively details the data analyses of the questionnaire items related to male and female teachers' behavioral intentions about the use of MT in Saudi PYP EFL classrooms. Both the groups of male and female respondents assigned the highest value to item 7 'MT should be used in the Saudi university PYP EFL classrooms' and item 8 'teacher should consciously use MT in Saudi PYP EFL university classrooms'. It is also worth mentioning here that male respondents ranked three items 7, 8, and 12 'Bilingual teachers can expedite the process of learning English equally significant and placed them first. Moreover, the lowest SD (. 80926) for item number 7 and 8 implies that male faculty respondents reflected high consensus with each other about the significance of these items. The data also showed that male and female respondents reported a difference in views about items 7 and 8 . However, item 12 was also considered as the most important item by both groups and high SD (i.e. 1.02708 for males, and 1.73799 for females) for both the sample groups reflected no general agreement among the respondents about its significance. Such findings can be deemed as unusual, since they break the myth of continuous use of TL, and most importantly the effectiveness of native speakers. Macswan (1997, p. 47) explained the position of a bilingual teacher: "Children's attitudes toward language alteration are greatly affected by the attitudes of their caregivers. Recognition on the part of the teachers of the expressive power of code-switched discourse, and the sophisticated linguistic knowledge required to effectively employ the mode, should serve to alter the prejudicial opinions they have about the practice". Accordingly, such finding necessitates that those who are teaching English in KSA need to exploit this positive trend to help out the students with MT but the ultimate goal should be to use TL.

Moreover, the sample groups assigned the highest mean values to items which were related to the role of using TL. These results indicated that students should be exhorted to get benefit from the bilingual teachers to practice TL in and outside the classroom. On the other side, female respondents identified items 12,10, and 11 as respectively high ranked items. These highest ranking items strongly suggest that the participants of this study know that the use of MT enhances students' proficiency and it gears up active use of TL. Thus, on the basis of the present study results, it can be claimed that MT can be used to learn TL, and slowly the use of TL becomes automated without any inhibition or additional aid of MT. This finding aligns with Eldridge's claim (1996, p. 303) who states that "messages are reinforced, emphasized or clarified where the messages have already been transmitted in one code but not understood." The male participants assigned the third highest value to the item 10 'MT is an essential technique in Saudi PYP EFL classroom discourse'

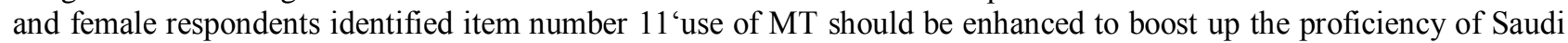
EFL students' for the same third position. This is a premier level of awareness in both sample groups, and it also goes with the conceptions of Aguirre (1988) who claimed that "language alternations or use of MT in the classroom are obvious and unavoidable and educators should regard language alternations as a communicative strategy employed by the students learning a second language." The fourth highest value was assigned to item 9 'habits of using MT must be nurtured among the Saudi PYP EFL university students' by male faculty respondents.

Conversely, female faculty respondents ranked item 8 'teacher should consciously use MT in Saudi EFL university classrooms' in the fourth position. The fifth highest value was assigned to item 9 'habits of using MT must be nurtured among the Saudi EFL university students and the sixth position was assigned to item 7 'MT should be used in the Saudi university EFL classrooms' by female respondents. The data analysis reveal that learning English language becomes 
much easier if English teachers make their classes interactive by employing a variety of exercises and providing students with ample opportunities to practice TL in classrooms. Similarly, both sample groups agreed that students should be involved in such activities that could ensure maximum interaction in TL among the students as well as with the faculty members. Also, the results of the present study highly recommend the well planned use of MT.

Moderately low values are identified in items 11 and 10 by male respondents, while female respondents similarly reported low values to items 8, and 11. Cohort of both sample groups totally negated the idea of nurturing habits of using MT among Saudi PYP EFL classrooms' students, and they also delimited the scope of disproving it as an essential technique. This result completely aligns with the findings of Gulzar \& Al Asmari (2013) who reported that free trend of using languages other than TL can be perilous for foreign language learners. The participants of the present study also supported the use of MT as a pedagogical technique by assigning moderate values to it. The lowest mean values were calculated for the items 9 by male members, and items 7, 8, and 9 by female faculty respondents. The differences of perceptions may be due to the fact that the participants of this study teach their male and female students in different setups, and each setup requires different prerequisites. Further, the different societal norms and the segregated working and environment in Saudi Arabia may be a reason behind this division of mindset.

The present study data analysis indicate that both sample groups showed differences with each other in most of the items $(7,8,9,10$, and 11) and agreed on only item 12 out of 6 items. The data generated through the second part of the questionnaire revealed interesting results regarding the utility of MT in Saudi PYP EFL classrooms. The values assigned by male respondents suggested more consensuses due to the low percentage of SD (see table 2), whereas females reflected low consensuses as they assigned comparatively higher SD (see table 2) values of the items. Moreover, the female respondents reported significantly higher values as compared to their male counterparts. The current results explicitly show differences among both sample groups as female respondents did not seem to consider those items significant. Consequently, the values assigned by both groups towards behavioral intentions of MT are mainly in favour of accepting the second hypothesis of the present study.

\section{Perceptions about the Use of Different Reasons for MT}

The importance of all the variables was analyzed individually to understand their significance in Saudi PYP EFL classroom discourse.

TABLE 3:

EFL TEACHERS' PERCEPTIONS ABOUT THE USE OF DIFFERENT REASONS FOR MT USE IN THE SAUDI PYP CLASSROOMS

\begin{tabular}{|c|c|c|c|c|c|c|c|c|c|}
\hline \multicolumn{2}{|c|}{$\begin{array}{l}\text { 13. Do you think that the following reasons enhance the } \\
\text { use of MT in Saudi PYP EFL university classrooms? }\end{array}$} & \multirow{2}{*}{$\begin{array}{l}\text { Groups :Mal } \\
\text { es \& Females } \\
\text { females }\end{array}$} & \multirow{2}{*}{$\begin{array}{l}\mathrm{n} \\
44\end{array}$} & \multirow{2}{*}{$\begin{array}{l}\mathrm{M} \\
3.6591 \\
\end{array}$} & \multirow{2}{*}{$\begin{array}{l}\text { SD } \\
1.96413 \\
\end{array}$} & \multirow{2}{*}{$\begin{array}{l}\mathrm{T} \\
-1.443- \\
\end{array}$} & \multirow{2}{*}{$\begin{array}{l}\text { df } \\
93\end{array}$} & \multicolumn{2}{|c|}{$\mathrm{p}$ value } \\
\hline i. & Use of clarification in Saudi PYP EFL university & & & & & & & .000 & $\mathrm{p}<$ \\
\hline & classrooms? & males & 51 & 4.0784 & .62748 & $-1.358-$ & 50.569 & & 0.05 \\
\hline \multirow[t]{2}{*}{ ii. } & \multirow{2}{*}{$\begin{array}{l}\text { Use giving instructions in Saudi PYP EFL } \\
\text { university classrooms? }\end{array}$} & females & 44 & 3.9318 & 1.95767 & .165 & 93 & .165 & $\mathrm{p}>$ \\
\hline & & males & 51 & 3.8824 & .81602 & .156 & 55.780 & & 0.05 \\
\hline \multirow[t]{2}{*}{ iii. } & \multirow{2}{*}{$\begin{array}{l}\text { Use of translation in Saudi PYP EFL university } \\
\text { classrooms? }\end{array}$} & females & 44 & 3.0909 & 2.19744 & $-.794-$ & 93 & .036 & $\mathrm{P}<$ \\
\hline & & males & 51 & 3.3529 & .79558 & $-.750-$ & 52.696 & & 0.05 \\
\hline \multirow[t]{2}{*}{ iv. } & \multirow{2}{*}{$\begin{array}{l}\text { Use of linguistic competence in Saudi PYP EFL } \\
\text { university classrooms? }\end{array}$} & females & 44 & 3.9318 & 2.19299 & .668 & 93 & .273 & $\mathrm{p}>$ \\
\hline & & males & 51 & 3.7059 & .94433 & .635 & 56.613 & & 0.05 \\
\hline \multirow[t]{2}{*}{ v. } & \multirow{2}{*}{$\begin{array}{l}\text { Use of topic shift in Saudi PYP EFL university } \\
\text { classrooms? }\end{array}$} & females & 44 & 3.5000 & 2.42564 & $-.082-$ & 93 & .019 & $\mathrm{p}<$ \\
\hline & & males & 51 & 3.5294 & .75771 & $-.077-$ & 50.238 & & 0.05 \\
\hline \multirow[t]{2}{*}{ vi. } & \multirow{2}{*}{$\begin{array}{l}\text { Use of ease of expression in Saudi PYP EFL } \\
\text { university classrooms? }\end{array}$} & females & 44 & 3.6818 & 2.62167 & $-.416-$ & 93 & .010 & $\mathrm{P}<$ \\
\hline & & males & 51 & 3.8431 & .83361 & $-.391-$ & 50.498 & & 0.05 \\
\hline \multirow[t]{2}{*}{ vii. } & \multirow{2}{*}{$\begin{array}{l}\text { Use of emphasis in Saudi PYP EFL university } \\
\text { classrooms? }\end{array}$} & females & 44 & 3.6364 & 2.68580 & $-.829-$ & 93 & .006 & $\mathrm{p}<$ \\
\hline & & males & 51 & 3.9608 & .72002 & $-.777-$ & 48.338 & & 0.05 \\
\hline \multirow[t]{2}{*}{ viii } & \multirow{2}{*}{$\begin{array}{l}\text { Use of checking understanding in Saudi PYP } \\
\text { EFL university classrooms? }\end{array}$} & females & 44 & 3.7500 & 2.83766 & $-.361-$ & 93 & .063 & $\mathrm{p}>$ \\
\hline & & males & 51 & 3.9020 & .92206 & $-.340-$ & 50.828 & & 0.05 \\
\hline \multirow[t]{2}{*}{ ix } & \multirow{2}{*}{$\begin{array}{l}\text { Use of repetitive function in Saudi PYP EFL } \\
\text { university classrooms? }\end{array}$} & females & 44 & 3.6818 & 2.98658 & .438 & 93 & .045 & $\mathrm{P}<$ \\
\hline & & males & 51 & 3.4902 & .85726 & .411 & 49.117 & & 0.05 \\
\hline \multirow[t]{2}{*}{$\mathrm{X}$} & \multirow{2}{*}{$\begin{array}{l}\text { Use of creating a sense of belonging in Saudi } \\
\text { PYP EFL university classrooms? }\end{array}$} & females & 44 & 3.9545 & 3.02666 & .689 & 93 & .254 & $p>$ \\
\hline & & males & 51 & 3.6471 & .93431 & .648 & 50.070 & & 0.05 \\
\hline
\end{tabular}

Table 3 details the results generated by both sample groups of the present study to elicit their responses towards the reasons that enhance the use of MT in Saudi PYP EFL classrooms. Male PYP EFL respondents assigned high values such as first, second, and third to items 1, 7, and 8 respectively, while female respondents assigned high values to items $10,4,2$, and 8 respectively. Extremely high value was assigned by the female respondents to the item 10 concerning EFL teachers who are friendly or create a sense of belonging. In the same vein, Crystal (1987, p. 14) states that "switching commonly occurs when an individual wishes to express solidarity with a particular social group. Rapport is established between the speaker and the listener when the listener responds with a similar switch". On the other hand, male faculty respondents ranked it seventh. Such results also reflect that the prevailing level of formality and informality of male and female teachers with their students is not at the same level in Saudi PYP EFL classrooms discourse. The present study findings support the study of Gulzar \& Al Asmari (2013), conducted in the same context to determine the effects of teachers' nonverbal communication on the learnability of the adult Saudi EFL learners, which revealed that Saudi female teachers were friendlier compared to their male counterparts. 
The female participants of the present study rated item 4 'related to the significance of linguistic competence' as the second highest reason for the use of MT in Saudi PYP EFL classrooms. According to male teachers' view point, this reason does not prevail as a significant factor for the use of MT as they ranked it sixth. Flyman-Mattson and Burenhult (1999) explained that teachers' use of MT due to linguistic insecurity may damage the students' confidence in the teachers' proficiency in the foreign language. A possible solution for the teacher might, therefore, be to avoid words or structure he/she cannot control or quite simply restructure the utterances. Considering it as a vital issue, Crystal (1987, p. 112) contends that "a speaker may not be able to express him/herself in one language; so, he/she switches to the other to compensate the deficiency." This kind of conception in the classroom can be risky for EFL teachers. Furthermore, female respondents graded item 8 about 'the use of ease of expressions' at third position and fourth highest rating was determined for item 6 'checking understanding'. However, male respondents identified items 8 and 6 at third and fourth positions respectively. Interestingly, only item 8 'checking understanding' is a reason for the use of MT for which both respondents identified its value at the position of number 3. This finding goes in line with Flyman-Mattson and Burenhult's claim (1999) in which they explained that the main reason for teachers' language alteration is to make students understand their talk. Gumperz (1982) and Brice (2000) have also identified the main function of language alteration as 'checking understanding'.

Female respondents ranked item 6 'related to ease of expression' at the fourth position, and male respondents identified item 2 'giving instructions effectively' at the position of number four. It is important to clarify here that moderate low values such as fourth, fifth and sixth are identified in items 9 , 1, and 7, by female respondents and male respondents ranked items 2, 6, and 4 for the same position. Item 10 'creating a sense of belonging', was ranked relatively high mean value and it was placed in seventh position by male respondents. Conversely, item 5 'regarding topic shift' was ranked seventh by female participants and male respondents identified 'topic shift' as the eighth important reason for the use of MT.

Flyman-Mattson and Burenhult (1999) clarified the significance of use of MT at certain points and claimed that the message is so important that the teacher is not willing to risk a misinterpretation. As such, MT is used to get the students' attention. In the current study, however, female respondents graded item 3 concerning 'translation' at the eighth position. Also, female participants ranked item 2 'giving instructions effectively', and item 4 linguistic competence at the position of number 2, and they also ranked items 6 and 9 at fourth position. The male participants of the study ranked item 9 'repetitive function' at number nine in the priority list and item 3 'translation' at the position of number 10. Male respondents' identification regarding item 3 'concerning translation' shows their high level of awareness about different reasons for the use of MT. For example, Krashen's views (1985, p. 81) also supported the findings of the male respondents and when he delineates that when teacher translates the students listen to the message in their own language and pay no intention to the English input. Atkinson (1987) also warned that due to excessive use of translation students begin to feel that they have not 'really' made clear or understood any item of language until it has been translated. Similarly, in this study, the findings suggest a careful use of MT especially while providing a translation. However, both sample groups reflected their perceptions in accordance with the views of the above mentioned linguists, and it proves that their perceptions are at a maturity level regarding the use of translation in Saudi PYP EFL classrooms. As far as lowest mean values of female respondents are concerned, the lowest mean values for the positions of seventh and eighth are identified through items 5 and 3. Male respondents identified items 10, 5, 9 and 3 for $7^{\text {th }}, 8^{\text {th }}, 9^{\text {th }}$ and $10^{\text {th }}$ positions.

Seemingly, the values assigned by both sample groups towards perceptions about the use of different reasons for MT are mainly in favour of approving the third hypothesis of this survey study. An interesting finding is that both the groups of the present study assigned medium values to the assumptions concerning use of MT is an effective tool in comprehending technical information and understanding TL material. On the other side, both groups strongly believe that language learning is facilitated if teachers use MT to make the interaction simple and easy with students. It may be due to the fact that the cohort of the present study bears a natural liking towards the well thought-out use of MT but they also confirm that bilingual teachers can better facilitate learning a foreign language, and use of MT as a technique also contributes positively to achieve English language proficiency. As far the least preferred items are concerned, both groups assigned the minimum values to the items stating that nurturing a habit of using MT among students, and use of MT with proficient students. The overall results of the present study reflect that the respondents are well aware and familiar with the prerequisites of the use MT and TL in Saudi PYP EFL classrooms. However, they graded the significance of reasons for the use of MT differently, and accordingly the values assigned by both of these groups about the use of different reasons for MT are mainly in favour of accepting the third hypothesis of the present perceptive study.

\section{CONCLUSION AND RECOMMENDATIONS}

The present study comprehensively investigated male and female EFL teachers' perceptions towards the dynamic use of MT in Saudi PYP classrooms along gender lines. On the basis of the present study results, it can be concluded that EFL male and female teachers provided very in-sighted and meaningful opinions about the pedagogical implications which may help teachers to reset classroom discourse patterns. Nevertheless, wider differences were detected in the all three sections of the questionnaire. Thus, the present study accepts all three null hypotheses set for the present study. 
It can be concluded that the sample groups represented by the cohort of this study recommended more professional use of MT to achieve the purpose of high English language proficiency for Saudi PYP EFL learners. Moreover, the participants of the present study confirmed the significance of MT and claimed that its prudent use is imperative for Saudi PYP EFL learners to learn English if they want to be academically successful. Another vital finding of this investigation is that PYP EFL male and female teachers believe that students can learn TL easily if teachers come from a bilingual background. The present study findings also reveal that EFL faculty should take extra measures to achieve maximum pedagogical benefits in Saudi PYP EFL classrooms by the proper use of MT and TL. Due to some misunderstandings about the use of MT, educators, course developers and teachers cannot devise classroom strategies based on the appropriate use of MT. Moreover, due to these unclear guidelines related to the medium of instruction, male and female EFL teachers are in a perplexed situation about the use of language(s) such as MT and TL in Saudi PYP EFL classrooms. The teachers do not know about the extent of the use of MT in Saudi PYP EFL classroom discourse to cater to the needs of the students. Needless to say, it can be extremely difficult for a language teacher to create a balance between TL and MT in Saudi PYP EFL classrooms. Such a situation demands immediate attention from all the stakeholders. Moreover, this serious situation might be a main reason for the assumed students' low proficiency in the TL and due to which teachers' productivity is also suffering.

In a nutshell, it can be safely said that the use of MT in Saudi PYP EFL classrooms can basically be deemed as a motivation for Saudi students and its appropriate use not only motivates them to learn English language but also makes it a friendly venture. As such, it is strongly recommended that language policy embraces a language trend where the sensitive issue of percentage of MT in reference to Saudi PYP EFL classroom situation. Because each teacher uses the discretionary power of using MT or TL, the students' competence process might be hampered. EFL teachers need to ask colleagues or classroom advisers to observe their classes to note down the plus and minus points of their interactional patterns and/or audio record a number of lessons to reflect on their interactional patterns in Saudi Universities EFL classroom discourse. The recommendations of the present study can also be utilized by policy planners and curriculum developers to establish the role of MT and TL for the academic needs of Saudi PYP EFL classroom interactants. With the settlement of these issues, teachers and students both can establish classroom discourse in accordance with the requirements of TL learning demands. Moreover, it can be recommended on the basis of the results of the present study that both male and female EFL teachers in Saudi PYP classrooms need to be made aware of the limitations of MT because the insensible use of MT can have long-lasting and harmful ramifications on the learners' production of the TL.

\section{REFERENCES}

[1] Abbad, A. (1988). "An Analysis of Communicative Competence Features in English Language Texts in Yemen Arab Republic", PhD Dissertation, University of Illinois at Urbana-Champaign (IL).

[2] Abed, G.T. (2003). "Unfulfilled Promise: Why the Middle East and North Africa Region has Lagged in Growth and Globalization, Finance and Development", IMF/World Bank, Washington, D.C. pp. 10-17.

[3] Aguirre, A. (1988). Code-switching, intuitive knowledge, and the bilingual classroom. In H.S. Garcia \& R.C. Chavez (Eds.), Ethnolinguistic issues in education (pp.28-38). Lubbock, TX: Texas Tech University, College of Education.

[4] Al-Abedalhaq, F. and O., Samdi. (1996). "Spread of English and westernization in Saudi Arabia". World Englishes, 15(3), pp. 307-317.

[5] Alam, M.A., Husain, S.M. and B.A., Khan. (1988). "A study of the attitudes of students, teachers and parents towards English as a foreign language in Saudi Arabian public schools". Ministry of Education, Educational Development, the General Directorate of Research and Evaluation, Saudi Arabia.

[6] Al-Mutawa, N. (1994). "Factors influencing English language teaching and learning in the secondary schools of Kuwait". Educational Sciences, 1(2), Cairo University: pp. 33-62.

[7] Atkinson, D. (1993).Teaching Monolingual classes: Using L1 in the classroom. Harlow: Longman Group Limited.

[8] Auer, J. (1995). The Pragmatics of Code-Switching: A Sequential Approach. In L. Milroy \& P. Muysken (Eds.), One Speaker, Two Languages: Cross-disciplinary Perspectives on Code-switching. (PP.115-135). Cambridge: University Press.

[9] Auer, P. (1998). Code switching in Conversation: Language, Interaction and Identity. London; New York: Routledge.

[10] Baker, C., \& Jones, P., S. (1998). Encyclopaedia of Bilingualism and Bilingual Education. Clevedon, UK: Multilingual Matters.

[11] Brice, A. (2000). Code switching and Code mixing in the ESL Classroom: A Study of Pragmatic and Syntactic Feature. Advances in Speech Language Pathology. Journal of the Speech Pathology Association of Australia, 20(1), 19-28

[12] Brown, K. (1995). World Englishes: To Teach or not to Teach? World Englishes, 14 (2), 233-245.

[13] Brumfit, C. (1984). Communicative Methodology in Language Teaching: The Roles of Fluency and Accuracy. London: Cambridge University Press.

[14] Burenhult, N. \& Flyman-Mattson, A. (1999). Code switching in Second Language Teaching of French. Retrieved on June 20, 2007 , from the World Wide Web: http://www.google.com/search?q=cache:GbFBmAtk8TAJ:www.ling.lu.se/disseminations/pdf/47/Flyman_Burenhult.pdf+classr oom+discourse+in+bilingual+context\&hl=en.

[15] Cook, V. (2001). Second language learning and language teaching. London: Edward Arnold.

[16] Crystal, D. (1997). The Cambridge Encyclopaedia of Language. Cambridge: Cambridge University Press.

[17] Dehbozorgi, E. (2012). Effects of attitude towards language learning and risk-taking on EFL students' proficiency. International Journal of English Linguistics, 2(2), 41-48.

[18] Dornyei, Z. (2005). The Psychology of the Language Learner. Mahwah, New Jersey: Lawrence Erlbaum.

[19] Di Sciullo, A.-M. (1986). Government and Code-mixing. Journal of Linguistics 22, 1-24. 
[20] Eastman. (1995.) Codeswitching, 123-142. Clevedon: Multilingual Matters.

[21] Ellis, R. (1985). Understanding second language acquisitions. Oxford: Oxford University Press.

[22] Eldridge, J. (1996). Code switching in Turkish Secondary School. ELT Journal, 50, 4: 303-311.

[23] Genesee. F, Paradis. J, \& Crago, MB. (2004). Dual Language Development \& Disorders: A Handbook on Bilingualism \& Second Language Learning. Baltimore, Maryland: Brookes.

[24] GÖKÇE, S. (2008). Attitudes and motivational intensity of foreign language learners at vocational high school: A comparative study. Maters Thesis submitted to The Graduate School of Social Sciences of Middle East Technical University. Available online http://etd.lib.metu.edu.tr/upload/3/12609935/index.pdf.

[25] Grosjean, F. (1982) Life with two Languages: An Introduction to Bilingualism. Cambridge, Massachusetts: Harvard University Press.

[26] Grosjean, F., \& Soares, C. (1984). Bilinguals in a monolingual and a bilingual speech mode: The effect on lexical access, Memory and Cognition 12, pp. 380-386.

[27] Gumperz, J.J. (1982). Language and Social Identity. Cambridge: Cambridge University Press.

[28] Gulzar, M.A. (2010). Code-Switching: Awareness about Its Utility in EFL/ESL Classroom Discourse, Bulletin of Education and Research, Vol.32 No.2, pp 1-14, Institute of Education and Research, University of the Punjab, Pakistan.

[29] Gulzar, M.A. \& Abdulrahman A.A. (2013). Intra-sentential Patterns of Code-mixing between Bilingual Male and Female Teachers: A Comparative Study. Volume 97 No 3, (2013), pp. 411-429, European Journal of Scientific Research.

[30] Gulzar, M.A. \& Abdulrahman A.A. (2013). Effects of Teachers' Nonverbal Communication on the Learnability of the Adult Saudi EFL Learners: A Case Study. Volume 96 No 4 (2013) pp. 553-571, European Journal of Scientific Research. http://www.europeanjournalofscientificresearch.com/ISSUES/EJSR_96_4.htm.

[31] Hakuta. (1986). Mirror of Language: The Debate on Bilingualism. New York: (Review by Genesse 1987 in Miami and Kennedy 1991). P. 11-12.

[32] Hamers, F.J., \& Blanc, A.H.M. (1989). Bilinguality and Bilingualism. Cambridge University Press, UK.

[33] Hammink, E.J. (2000). A Comparison of Code switching Behaviour and Knowledge of Adults and Children. Retrieved on March 28, 2007, from the World Wide Web: http:// www.google.com.

[34] Haugen, E. (1987). Blessing of Babel: Bilingualism and Language Planning Problems and Pleasures. Berlin \& New York: Montonde Gruyter. http://www.umanitoba.ca/education/symposium03/documents/MacKay03.pdf. url:http://www.google.com/search?q=cache: retrieved on $16^{\text {th }}$ April 2014.

[35] Heath, J. (1989). From Code-switching to Borrowing: Foreign and Diglossic Mixing in Moroccan Arabic. London: Kegan Paul International.

[36] Heller, M. (1992). The politics of code-switching and language choice. Journal of Multilingual Multicultural Development, 13, 123-142.

[37] Jakobson, R. and Morris H. (1956). Fundamentals of Language. The Hague: Mouton.

[38] Judith \& Wallat. (1981). Ethnography and language in educational settings. ABLEX Pub. Company UK.

[39] Kachru B.B. (1978). Code Mixing as Communicative Strategy in India: In International Dimension of Bilingual Education. (ed) Jame E. Alatis George Town University Press.

[40] Kamwangamalu, N. M. (1992). Mixers and Mixing English across Cultures. World Englishes, 11(2/3), pp.173-181.

[41] Karahan, F. (2007). Language attitudes of Turkish students towards the English language and its use in Turkish context. Journal of Arts and Sciences, 7, 73-87.

[42] Kikuchi, K. (2005). Student and teacher perceptions of learning needs: A cross analysis. Shiken, 9(2), 8-10. Available online http://www.jalt.org/test/na_3.htm. Retrieved on 31st April 2013.

[43] Klein, W. (1986). Second language acquisition. Cambridge, London: Cambridge University Press.

[44] Kobayashi, y. (2002). The Role of Gender in Foreign Language Learning Attitudes: Japanese female students' attitudes towards English learning. Gender and English, 14(2), 181-197. DOI: 10.1080/09540250220133021.

[45] Karahan, F. (2007). Language attitudes of Turkish students towards the English language and its use in Turkish context. Journal of Arts and Sciences, 7, 73-87.

[46] Macswan, J. (1999). A Minimalist Approach to Intra-sentential Code switching. New York; London: Garland Publishing.

[47] Makay, L.S. \& Hornberger, H.N. (1996). Sociolinguistics and Language Teaching. New York: Cambridge University Press.

[48] Martin-Jones, M. (1995). Code-switching in the Classrooms: Two Decades of Research. In L. Milroy \& P. Muysken (Eds.), One Speaker, Two languages: Cross-disciplinary Perspectives on Code-switching. (PP. 90-112). Cambridge: University Press.

[49] Martin-Jones, M. (2003). Teaching and Learning Bilingually: Towards an Agenda for Qualitative Classroom -Based Research. Retrieved on January 20, 2008, from World Wide Web: http://www.aber.ac.uk/ merwww/general/papers/mercSym-03-0408/marilyn.doc.

[50] Mehan, H. (1982). The Structure of Classroom Events. In P. Gilmore \& A. Glatthorn (Eds.), Children In and Out of School. (PP. 59-87). Centre for Applied Linguistics.

[51] Nunan, D., \& Lamb, A. (1998). Teacher Education for Multilingual Contexts: Models and Issues, In J. Cenoz \& F. Genesse (Eds.) (1998), Beyond Bilingualism: Multilingualism and Multilingual Education. Clevedon: Multilingual Matters.

[52] Rababah, G. (2003). "Communication Problems Facing Arab Learners of English: A Personal Perspective". TEFL Web Journal, 2(1). Retrieved October 17, 2009, from http://faculty.ksu.edu.sa/mdajani/Pages/ArabLearners.aspx.

[53] Sahu, R. (1999). "Improving English Language: Competence of Yemeni Learners". Yementimes, (5).

[54] Selinker, L. (1972). Interlanguage: International Review of Applied Linguistics, 10,209-31.

[55] Skiba, R. (1997). Code switching as a Countenance of Language Interference. The Internet TESL Journal.3, 10. Retrieved on June 11, 2007, from.” Internet TESL Journal. http://www.aitech.ac.jp/ iteslj/Articles/Skiba-CodeSwitching.html.

[56] Skutnabb-Kangas, T. (2000). Linguistic Genocide in Education or Worldwide Diversity and Human Rights. London: Erlbaum.

[57] Skutnabb-Kangas, T., \& Cummins, J. (Eds.) (1988). Minority Education from Shame to Struggle. Cleveden, Avon: Multilingual Matters. 
[58] Soku, D. (2011). Students' Attitudes towards the Study of English and French in a Private University Setting in Ghana. Journal of Education and Practice, 2(9), 19-31.

[59] Sridhar, S.N., \& Sridhar, K. K. (1980). The syntax and psycholinguistics of bilingual code-mixing. In Studies in the Linguistic Sciences. 10, 203-215.

[60] Stevens, R. (1983). A theoretical model of the language learning/language teaching process. Working Papers On Bilingualism, 11, 129-152.

[61] UNESCO. (1997). Statistical Year Book (1997). Paris: UNESCO Publishing \& Berman Press.

[62] Valdes-Fallis, G. (1977). Code-switching among bilingual Mexican-American women: Towards an understanding of sexrelated language alternation. International Journal of The Sociology of Language, 7, 65-72.

[63] Wenden, A. (1991). Learner strategies for learner autonomy. London: Prentice Hall.

[64] Zughoul, M.R., \& Taminian, L. (1984). The Linguistic Attitudes of Arab University Students: Factorial Structure and Intervening Variables. International Journal of the Sociology of Language, 50, 155-179.

AbdulRahman Al Asmari received his PhD in Applied linguistics and an MA in CALL from the University of Melbourne, Australia. He has been holding the office of the Dean Preparatory Year Programme since its inception at Taif University Saudi Arabia. He is also working as Associate Professor \& Director of English Language Center. His research interests include: EFL/ESL Teaching; technology-enhanced language learning/teaching; language program evaluation; sociolinguistics and language learning and computer-based statistical data analysis. Dr AbdulRahman is also heading many committees to cater to the academic and administrative issues of the Taif University. 